\title{
MANAJEMEN PENDIDIKAN INKLUSI DI SMAN 1 PADANGAN
}

\author{
Nanda Rizki Wiliyanto 1) \\ 1 Universitas Negeri Semarang Indonesia \\ Email: nandhahemmm@students.unnes.ac.id ${ }^{1}$
}

\begin{abstract}
Abstrak: Manajemen Pendidikan Inklusi, Di lembaga pendidikan inklusi bertujuan untuk memberikan kesempatan bagi anak-anak disabilitas atau berkebutuhan khusus agar dapat mengikuti pembelajaran seperti layaknya anak-anak normal lainnya. Manajemen pendidikan inklusi ialah kegiatan, merencanakan, mengimplementasi, dan mengawasi segala kegiatan (program), guna agar terselenggaranya pendidikan bagi seluruh peserta didik termasuk peserta didik berkebutuhan khusus dalam rangka mencapai tujuan. Jenis penelitian ini termasuk penelitian kualitatif dan menggunakan teknik analisis deskriptif, guna mengetahui permasalahan dan mendapatkan data yang akurat, peneliti menggunakan metode observasi, wawancara serta dokumentasi. Hasil penelitian ini dapat dikatakan bahwa dalam pembahasan manajemen pendidikan inklusi yang terlihat menonjol adalah penekanan terhadap pengelolaan program pendidikan inklusi. yakn Perencanaan (planning) adalah fungsi dasar manajemen, karena dalam organizing, actuating, dan controlling pun harus terlebih dahulu direncanakan. Agar resiko yang ditanggung itu relatif kecil, hendaknya semua kegiatan, tindakan, dan kebijakan direncanakan terlebih dahulu. Pengorganisasian (organizing) Fungsi pengorganisasian (organizing = pembagian kerja) berkaitan erat dengan fungsi perencanaan, karena pengorganisasian pun harus direncanakan. Pelaksanaan (Actuanting) merupakan menggerakkan orang-orang agar bekerja sesuai dengan tugas yang diberikan kepadanya sehingga dapat mencapai tujuan yang telah ditetapkan. Dalam melaksanakan tugas pokok dan fungsi yang diberikan atasan kepada bawahan atau anggota harus dilaksanakan dengan rasa penuh tanggung jawab, totalitas, dan maksimal. Perlu adanya kerjasama yang baik dari atasan kepada bawahan atau anggota maupun antar sesama anggota dalam melaksanakan tugas-tugas. Sehingga tujuan yang akan dicapai dapat diwujudkan. Pengawasan (controlling) merupakan bagian dari manajemen yang penting untuk dilakukan, karena dalam pengawasan akan mengetahui sebuah program berjalan dengan lancar atau terselip sebuah kendala. Pengawasan memang berusaha semaksimal mungkin mengawal program-program yang telah direncanakan supaya berjalan maksimal dan sebagaimana mestinya.
\end{abstract}

Kata Kunci : Manajemen; Pendidikan Inklusi

Abstract: Inclusive Education Management, In inclusive education institutions aim to provide opportunities for children with disabilities or special needs to be able to participate in learning like other normal children. Inclusive education management is an activity, planning, implementing, and supervising all activities (programs), in order to provide education for all students, including students with special needs in order to achieve goals. This type of research includes qualitative research and uses descriptive analysis techniques, in order to find out the problem and get accurate data, the researcher uses the method of observation, interviews and documentation. The results of this study can be said that in the discussion of inclusive education management that stands out is the emphasis on the management of inclusive education programs. that planning (planning) is a basic function of management, because in organizing, actuating, and controlling must first be planned. So that the risk borne is relatively small, all activities, actions, and policies should be planned in advance. Organizing The organizing function (organizing = division of labor) is closely related to the planning function, because organizing must be planned. Actuation is moving 
people to work in accordance with the tasks assigned to them so that they can achieve the goals that have been set. In carrying out the main tasks and functions given by superiors to subordinates or members, they must be carried out with a full sense of responsibility, totality, and maximum. There needs to be good cooperation from superiors to subordinates or members as well as among fellow members in carrying out tasks. So that the goals to be achieved can be realized. Controlling is an important part of management, because in supervision one will know if a program is running smoothly or if there is an obstacle. Supervision is trying as much as possible to oversee the programs that have been planned so that they run optimally and as they should.

Keywords : Inclusive; Education Management

\section{Pendahuluan}

Pendidikan inklusi yaitu sistem pendidikan yang harus menerima berbagai macam kultur serta segala perbedaan yang ada pada setiap siswa. ${ }^{1}$ PBB menyelenggarakan the world education forum yang di hadir oleh 155 negara dan puluhan NGO dar seluruh dunia. Forum yang merupakan follow up dari konvensi hak ini melahirkan deklarasi "Education for all” yang menargetkan pada tahun 2000 (sekarang diperbarui menjadi 2015) semua anak di dunia harus mendapatkan kesempatan untuk menyelesaikan pendidikan dasar. Lebih lanjut, dalam pernyataan Salamanca, disebutkan bahwa prinsip mendasar dari pendidikan inklusi adalah selama memungkinkan, semua orang seyogyanya belajar bersama- sama, dengan tidak memandang kesulitan ataupun berbedaan yang mungkn ada pada diri mereka, termasuk perbedaan dalam karakteristik fisik maupun kapasitas intelektualnya. ${ }^{2}$

Sekolah yang mengimplementaskan ideologi pendidikan inklusi harus mengenal dan merespon setiap kebutuhan yang berbeda-beda dari setiap siswanya. Seperti mengakomodasi berbagai macam gaya belajar, serta menjamin di berikannya pendidikan yang berkualitas kepada semua siswa. Untuk itu tentunya harus melalui manajemen yang baik, pemilihan strategi pengajaran yang tepat, pemanfaatan sumberdaya dengan sebaik baiknya, dan penggalangan kemitraan dengan masyarakat sekitarnya.

Pasal 31 UUD 1945 yang menyatakan bahwa setiap warga Negara berhak mendapatkan pendidikan dan pengajaran yang layak. Jadi sebagai konsekuensi dari undang-undang tersebut, maka negara berkewajiban melaksanakan pendidikan sebagai suatu upaya untuk mencerdaskan anak bangsa dengan tanpa terkecuali. Oleh karena itu, untuk menggapai pendidikan yang adil, perlu ada cara yang strategis yakni melalui sistem pendidikan inklusi yang terorganisir dan terpadu. ${ }^{3}$

SMAN 1 Padangan Bojonegoro merupakan salah satu sekolah yang berani melakukan inovasi menerapkan metode pendidikan inklusi. Menjadi sekolah inklusi tentunya membutuhkan berbagai adaptasi sistem dan dukungan fasilitas yang berbeda dengan sekolah regular lainnya. Sekolah harus mempersiapkan diri dengan melakukan inovasi-inovasi serta manajemen yang baik agar semua siswa dapat mengikuti pembelajaran secara nyaman dan baik pula. Disamping itu, sekolah juga di bisa memberikan penyadaran kepada semua civitas akademika bahwa siswa dan siswi berkebutuhan kusus juga dapat mengikuti pendidikan disekolah umum, seperti disekolah mereka. ${ }^{4}$

Inovasi- inovasi yang dilakukan terhadap sekolah itu dapat dimulai dari pengenalan terhadap pendidikan inklusi itu sendiri, identifikasi difabel, pengembangan kurikulum, metode mengajar, media pembelajaran, kompetensi guru, evaluasi, hingga layanan akademik maupun non akademik yang harus disusun sedemikian rupa dan tentunya membutuhkan waktu dan biaya yang tidak sedikit. ${ }^{5}$ Dinamika

\footnotetext{
${ }^{1}$ Education For All tahun 1990 di Jomtien, Tailand.

${ }^{2}$ Ro'fah dan Andayani, Inklusi Pada Pendidikan Tinggi: Best Practices Pembelajaran dan Pelayanan Adaptif Bagi Mahasiswa Difable Netra (Yogyakarta: PSLD UIN SuKa, 2010), 14-15.

${ }^{3}$ UU RI No. 20 tahun 2003. Tentang Sistem Pendidikan Nasional. (Jakarta: Cemerlang, 2003), 109.

${ }^{4}$ Malik Fajar, Holistika Pemikiran Pendidikan. (Jakarta: Raja Grafindo Persada, 2005), 152-153.

5 Abdul Latif, Pendidikan Berbasis Nilai Kemasyarakatan (Bandung: Refika Aditama, 2007), 7.

145 | MUDIR: Jurnal Manajemen Pendidikan
} 
SMAN 1 Padangan dalam menjalankan proses pendidikan bagi siswa-siswanya yang menyatu antara siswa berkebutuhan khusus dengan siswa non berkebutuhan khusus, bagaimana evaluasi pembelajaran dilakukan menjadi menarik untuk dibicarakan dan diteliti lebih lanjut guna memberikan wacana baru tentang pendidikan inklusi, serta memberikan pandangan baru terhadap masyarakat bahwa siswa yang mempunyai kemampuan berbeda (berkebutuhan khusus) tidak hanya dapat bersekolah di SLB saja akan tetapi juga dapat mengikuti sekolah-sekolah yang umum dengan menggunakan system pendidikan inklusi yang tentunya dapat meningkatkan wawasan serta kemandirian siswa tersebut.

\section{Metode Penelitian}

Peneliti menggunakan pendekatan penelitian kualitatif. Menurut Moleong, "Penelitian kualitatif adalah suatu penelitian yang bermaksud untuk memahami fenomena tentang sesuatu yang dialami oleh subjek penelitian misalnya perilaku, persepsi, motivasi, tindakan dan lain-lain secara holistik, dan dengan cara mendeskripsikan ke dalam bentuk kata-kata dan bahasa". Sedangkan menurut Eko Sugiarto, "Penelitian kualitatif adalah jenis penelitian yang temuan-temuannya tidak diperoleh melalui prosedur statistik atau bentuk hitungan lainnya dan bertujuan mengungkapkan gejala secara holistik-kontekstual melalui pengumpulan data dari latar alami dengan memanfaatkan diri peneliti sebagai instrument kunci" ${ }^{\prime \prime}$. Sebab jika diamati, penelitian dengan pendekatan kualitatif merupakan bentuk penelitian yang kegiatan pokoknya adalah dalam penyajian datanya dilakukan dengan cara mendeskripsikan data dalam bentuk kata-kata dan bahasa tentang segala sesuatu yang berkaitan dengan objek penelitian, yakni tentang Manajemen Pendidikan Inklusi di SMAN 1 Padangan Bojonegoro.

\section{Data dan Sumber Data}

Secara umum sumber data penelitian kualitatif adalah tindakan dan perkataan manusia dalam suatu latar yang bersifat alamiah. ${ }^{8}$

\section{a. Data Primer}

Adalah data yang diperoleh dari sumber pertama melalui prosedur dan teknik pengambilan data yang dapat berupa interview, observasi, maupun penggunaan instrument yang khusus dirancang sesuai dengan tujuan. ${ }^{9}$ Dapat diartikan juga data yang diperoleh secara langsung dari lapangan. Data diperoleh dari informasi yang bersumber dari kepala sekolah, Waka Kesiswaan, guru pembimbing dan peserta didik.

\section{b. Data Sekunder}

Adalah data yang diperoleh dari sumber tidak langsung yang biasanya berupa data dokumentasi dan arsip-arsip resmi. Data tersebut seperti data kepustakaan yang terkait dengan literatur dan data penunjang lainnya. Jadi, kata-kata dan tindakan informan yang diamati atau diwawancarai merupakan sumber data utama dan dokumen atau sumber data tertulis lainnya merupakan sumber data tambahan

\section{Tekhnik Pengumpulan Data}

Observasi

Penelitian kualitatif menggunakan metode pengumpulan data dengan observasi. Metode ini digunakan untuk mendapatkan data yang lebih lengkap dan mengetahui tingkat kemampuan yang tampak. Observasi atau pengamatan merupakan suatu teknik atau cara pengumpulan data dengan jalan mengadakan pengamatan terhadap kegiatan yang sedang berlangsung. ${ }^{10}$ Data observasi berupa data

\footnotetext{
${ }^{6}$ Lexy J.Moleong, Metodologi PenelitianKualitatf (Bandung: PT Remaja Rosdakarya,2014, 6.

${ }^{7}$ Eko Sugiarto, Menyusun Proposal Penelitian Kualitatif: Skripsi dan Tesis: Suaka Media (Yogyakarta) : Diandra Kreatif,2017), 8.

${ }^{8}$ Lexy, J. Moleong, Metodologi Penelitian Kualitatif Edisi Revisi (Bandung : PT Remaja Rosdakarya offset), cet.33, 2014, 4

${ }^{9}$ Saifudin Azwar, Metode Penelitian (Yogyakarta: PT Pusaka Pelajar,2005), 36.

${ }^{10}$ Nana Syaodah Sukamdinata, Metode Penelitian Pendidikan (Bandung: PT Remaja Rosdakarya, 2008), 220.
} 
faktual cermat, terinci, mengenai keadaan lapangan, keadaan manusia dan situasi sosial dengan penelitian secara langsung. Metode ini digunakan untuk memperoleh data yang lebih lengkap tentang manajemen Pendidikan inklusi di SMAN 1 Padangan.

Wawancara

Penelitian kualitatif menggunakan metode pengumpulan data dengan interview atau wawancara. Interview atau wawancara merupakan pertemuan dua orang untuk bertukar informasi dan ide melalui Tanya jawab, sehingga dapat dikonstruksikan makna dalam topik tertentu. ${ }^{11}$ Adapun jenis wawancara yang digunakan peneliti adalah wawancara bebas terpimpin. Menurut Suharsimi Arikunto, "Interview bebas terpimpin adalah melaksanakan interview, pewawancara membawa pedoman yang hanya merupakan garis besar tentang hal-hal yang akan ditanyakan dan untuk selanjutnya pertanyaanpertanyaan tersebut diperdalam". Dengan demikian suasana saat wawancara berlangsung akan lebih santai dan terkadang pertanyaan-pertanyaan yang diajukan kurang terkendali karena menanggapi informasi yang diberikan oleh narasumber

\section{Dokumentasi}

Penelitian kulitatif juga menggunakan metode pengumpulan data dengan metode dokumentasi. Dokumentasi ini berasal dari kata dokumen, yang berarti bahan-bahan tertulis. ${ }^{12}$ Dokumen merupakan catatan peristiwa yang sudah berlalu, bisa berbentuk tulisan, gambar, atau karya-karya monumental dari seseorang. ${ }^{13}$ Telaah dokumentasi merupakan salah satu teknik penting dalam suatu penelitian dengan mengumpulkan informasi yang telah ada pada lembaga terkait. Metode dokumentasi adalah metode pelengkap dan penunjang dari metode interview dan observasi. Karena metode ini penting guna menyakinkan hasil penelitian dengan adanya dukumentasi data yang kita perolah akan kuat. Dokumentasi ini gunakan untuk mempermudah dalam membantu dan menganalisa fenomenafenomena yang ditemukan di lapangan. Dalam metode dokumentasi ini peneliti mengumpulkan datadata yang dimiliki lembaga dan peneliti memformulasikan dan menyusunnya dalam bentuk laporan sesuai dengan kebutuhan yang diperlukan.

\section{Teknik Analisis Data}

Kegiatan menganalisa data merupakan kegiatan inti yang dilakukan untuk mengambarkan pemecahan suatu masalah, yang mana pada akhirnya akan melahirkan suatu kesimpulan dan saran. Kegiatan yang dimulai dari mengumpulkan data yang kemudian dianalisis, melakukan identifikasi terhadap data-data yang diperoleh, menyusun data-data, menjelaskan kemudian melahirkan suatu kesimpulan. Pada penelitian ini, teknik analisis data yang digunakan peneliti menggunakan model Miles and Huberman. Analisis data dalam penelitian kualitatif, dilakukan pada saat pengumpulan data berlangsung, dan setelah selesai pengumpulan data dalam periode tertentu. Pada saat wawancara, peneliti sudah melakukan analisis terhadap jawaban yang diwawancarai.

Menurut Miles and Huberman, "Aktivitas dalam analisis data kualitatif dilakukan secara interaktif dan berlangsung secara terus menerus sampai tuntas, sehingga datanya sudah jenuh. Aktivitas dalam analisis data, yaitu, data reduction, data display, dan conclusion drowing/verification" ${ }^{14}$

Langkah-langkah yang ditempuh peneliti dalam menganalisis data adalah sebagai berikut:

1. Reduksi Data (Data Reduction)

Reduksi data berarti merangkum, memilih hal-hal yang pokok, memfokuskan pada hal-hal yang penting, dicari tema dan polanya. Dengan demikian data yang akan direduksi memberikan gambaran yang lebih jelas, dan mempermudah peneliti untuk melakukan pengumpulan data

\footnotetext{
11 Sugiyono, Metode Penelitian (Bandung: Penerbit Alfa Beta, 2015), 317.

12 Suharsimi Arikunto, Prosedur Penelitian: Suatu Pendekatan Praktek (Jakarta: PT Rineka Cipta, 2002), 132.

${ }^{13}$ Sugiyono, Metode Penelitian Pendidikan, : Pendekatan Kuantitatif, Kualitatif, dan R\&D (Bandung: Alfabeta, 2016$), 274$.

${ }^{14}$ Sugiyono, Metode Penelitian Pendidikan,: Pendekatan Kuantitatif, Kualitatif, dan R\&D (Bandung: Alfabeta, 2016), 246

147 | MUDIR: Jurnal Manajemen Pendidikan
} 
selanjutnya, dan mencarinya bila diperlukan. ${ }^{15}$ Dapat diartikan reduksi data ini dilakukan dengan cara memilih, memusatkan perhatian terhadap data yang telah dipilih yang mana akan menghasilkan gambaran yang jelas yang akan mempermudah dalam pencarian jika diperlukan.

2. Penyajian Data (Data Display)

Dalam penyajian data selain menggunakan teks secara naratif, juga dapat berupa bahasa nonverbal seperti bagan, grafik, denah, matriks, dan tabel. Dengan mendisplay atau menyajikan data akan memudahkan untuk memahami apa yang terjadi selama penelitian berlangsung. Setelah itu perlu adanya perencanaan kerja berdasarkan apa yang telah dipahami. Miles and Huberman dalam penelitian kualitatif mengatakan bahwa penyajian data bisa dilakukan dalam bentuk uraian singkat, bagan, hubungan antarkategori, flowchart dan sejenisnya. Ia juga mengatakan bahwa yang paling sering digunakan untuk menyajikan data dalam penelitian kualitatif adalah dengan teks yang bersifat naratif. Semua data-data yang diperoleh dinarasikan ke dalam bentuk kata-kata sehingga terbentuk penjelasan yang sesuai dengan apa yang menjadi fokus penelitian.

\section{Penarikan Kesimpulan/Verifikasi Data (Conclusions drowing/Data Verification)}

Langkah terakhir dalam teknik analisis data adalah verifikasi data atau penarikan kesimpulan. Verifikasi data dilakukan apabila kesimpulan awal yang dikemukan masih bersifat sementara, dan akan ada perubahan-perubahan bila tidak dibarengi dengan bukti-bukti pendukung yang kuat untuk mendukung pada tahap pengumpulan data berikutnya. Bila kesimpulan yang dikemukan pada tahap awal, didukung dengan buktibukti yang valid dan konsisten saat penelitian kembali ke lapangan mengumpulkan data, maka kesimpulan yang dikemukan merupakan kesimpulan yang kredibel atau dapat dipercaya. ${ }^{16}$ Dalam penelitian kualitatif, kesimpulan yang didapat kemungkinan dapat menjawab fokus penelitian yang sudah dirancang sejak awal penelitian. Ada kalanya kesimpulan yang diperoleh tidak dapat digunakan untuk menjawab permasalahan. Hal ini sesuai dengan jenis penelitian kualitatif itu sendiri bahwa masalah yang timbul dalam penelitian kualitatif sifatnya masih sementara dan dapat berkembang setelah peneliti terjun ke lapangan. Harapan dalam penelitian kualitatif adalah menemukan teori baru. Temuan itu dapat berupa gambaran suatu objek yang dianggap belum jelas, setelah ada penelitian gambaran yang belum jelas itu bias dijelaskan dengan teori-teori yang telah ditemukan. Selanjutnya teori yang didapatkan diharapkan bisa menjadi pijakan pada penelitian-penelitian selanjutnya.

\section{Findings and Discussion}

Peneliti menyesuaikan dengan rumusan masalah dan tujuan penelitan, serta disesuaikan pula dengan teknik analisis data sehingga dapat diambil kesimpulan dari masalah yang diteliti. Diantaranya sebagai berikut:

\section{Manajemen Pendidikan Inklusi di SMAN 1 Padangan Bojonegoro}

Berdasarkan hasil penelitian yang telah dipaparkan dalam pembahasan manajemen pendidikan inklusi yang terlihat menonjol adalah penekanan terhadap pengelolaan program pendidikan inklusi. Dalam hal memanajemen Pak Sumarmin melakukan 4 langkah yakni Perencanaan (Planing), Pengorganisasian (Organizing), Proses Dan Pelaksanaan (Actuating), Pengawasan (Controling).

a. Perencanaan (Planing)

Perencanaan (planning) adalah fungsi dasar manajemen, karena dalam organizing, actuating, dan controlling pun harus terlebih dahulu direncanakan. Agar resiko yang ditanggung itu relatif kecil, hendaknya semua kegiatan, tindakan, dan kebijakan direncanakan terlebih dahulu.

\footnotetext{
${ }^{15}$ Sugiyono, Metode Penelitian Pendidikan Pendekatan Kuantitatif, Kualitatif, dan R\&D (Bandung: Alfabeta, 2016$), 249$.

16 Sugiyono,Metode Penelitian Kuantitatif Kualitatif dan R\&D, 252.
} 
Seperti yang diuatarakan Pak Sumarmin yang penulis temui dilapangan bahwa Kepala Sekolah memang seharusnya menguasai program-program lembaga, menetapkan tujuan, menyusun struktur, merumuskan keadaan dan lain-lain. ${ }^{17}$ Setiap perencanaan yang baik juga harus diskusikan kepada setiap waka juga supaya dalam pelaksanaannya bisa di kontrol dengan baik. Penyelenggaraan pengembangan program pendidikan inklusi di lembaga agar lebih efektif dan efisien. Kaitanya dengan menetapkan tujuan, menyususn struktur, merumuskan keadaan, dan mengelola SDM, dan Tinggal didukung dari pihak-pihak lain, dan beliau juga membebaskan kepada seluruh warga sekolah yang mempunyai ide atau rencana mengenai hal apapun khususnya tentang pengembangan program pendidikan inklusi.

Hal ini sesuai dengan teori yang menyatakan perencanaan pada dasarnya membuat keputusan mengenai arah yang akan dituju, tindakan yang akan diambil, sumberdaya yang akan diolah dan tehnik atau metode yang dipilih untuk digunakan, rencana mengarahkan tujuan organisasi dan menetapkan prosedur itu dapat berupa pengaturan sumber daya dan penetapan tehnik atau metode.

b. Pengorganisasian (Organizing)

Fungsi pengorganisasian (organizing $=$ pembagian kerja) berkaitan erat dengan fungsi perencanaan, karena pengorganisasian pun harus direncanakan. Pengorganisasian adalah fungsi manajemen dan merupakan suatu proses yang dinamis, Pengorganisasian dapat diartikan mengatur pekerjaan-pekerjaan yang harus dilakukan, pengelompokkan tugas-tugas dan membagi-bagikan pekerjaan kepada setiap karyawan, penetapan, departemendepartemen (subsistem) serta penentuan hubungan hubungan.

Pak Sumarmin memang telah melaksanakan sebagai mana mestinya kepala sekolah, beliau selalu menjaga keharmonisan dalam berorganisasi dan membagi tugas rata sesuai jabatan dari bawahan-bawahan beliau. Pak Sumarmin pula mendukung penuh segala program yang telah berjalan, dan beliau selalu memberi wejangan supaya saling mengisi kekosongan jika ada yang berhalangan.

Hal ini sesuai dengan teori Pengorganisasian atau organizing, yaitu proses yang menyangkut bagaimana strategi dan taktik yang telah dirumuskan dalam perencanaan didesain dalam sebuah struktur organisasi yang tepat dan tangguh, sistem dan lingkungan organisasi yang kondusi, dan bisa bekerja secara efektif dan efesien guna pencapaian tujuan organisasi.

c. Pelaksanaan (Actuating)

Dalam konteks fungsi manajemen, pelaksanaan merupakan menggerakkan orangorang agar bekerja sesuai dengan tugas yang diberikan kepadanya sehingga dapat mencapai tujuan yang telah ditetapkan. Dalam melaksanakan tugas pokok dan fungsi yang diberikan atasan kepada bawahan atau anggota harus dilaksanakan dengan rasa penuh tanggung jawab, totalitas, dan maksimal. Perlu adanya kerjasama yang baik dari atasan kepada bawahan atau anggota maupun antar sesama anggota dalam melaksanakan tugas-tugas. Sehingga tujuan yang akan dicapai dapat diwujudkan.

Dalam hal pelaksanaan kepala sekolah atau pengelola lembaga sudah berusaha mencukupi berbagai sarana penunjang yang memang sangat diperlukan oleh peserta didik baik peserta didik normal maupun peserta didik berkebutuhan khusus dalam hal pengajaran khususnya juga dalam hal pengembangan program pendidikan inklusi, namun juga secara bertahap kepala sekolah juga tak henti memberi dorongan motivasi terhadap semua warga sekolah terutama juga peserta didik.

17 Observasi Lapangan di SMAN 1 Padangan, Bojonegoro, 26 Oktober 2020.

149 | MUDIR: Jurnal Manajemen Pendidikan 
Pelaksanaan ini memang sudah baik, akan tetapi memang masih ada yang kurang seperti memberikan bimbingan dan binaan khusus untuk peserta didik berkebutuhan khusus agar merasa nyaman dalam mengikuti proses pembelajaran.

Hal ini sesuai dengan teori yaitu proses implementasi program agar bisa dijalankan oleh seluruh pihak dalam organisasi serta proses memotivasi agar semua pihak tersebut dapat menjanakan tanggung jawabnya dengan penuh kesadaran dan produktivitas yang tinggi.

d. Pengawasan (Controling)

Pengawasan ini dimaksudkan untuk memastikan agar anggota organisasi melaksanakan apa yang dikehendaki dengan mengumpulkan, menganalisis dan mengevaluasi infomasi serta memanfaatkannya untuk mengendalikan organisasi. Bahwa pengawasan sangat penting dilakukan agar dapat melihat adanya ketidaksesuaian antara harapan dan kenyataan dari kegiatan yang dilaksanakan.

Pengawasan memang berusaha semaksimal mungkin mengawal program-program yang telah direncanakan supaya berjalan maksimal dan sebagaimana mestinya.

Pengawasan merupakan bagian dari manajemen yang penting untuk dilakukan, karena dalam pengawasan akan mengetahui sebuah program berjalan dengan lanncar atau terselip sebuah kendala. dalam pengawasan Pak Sumarmin selalu berusaha memaksimalkan keberjalanan sebuah program yang ada agar program tersebut dapat berjalan maksimal. Pengawasan memang perlu kerjasama yang kuat dengan berbagai pihak khususnya para waka, dengan dibantu para waka maka informasi dapat segera tersampaikan. Pak Sumarmin juga tidak menutup kemungkinan jika beliau khilaf dalam sebuah tanggung jawab semua pihak guru bisa menegur beliau, yang pada intinya semua berjalur pada visi dan misi sekolah. Hal ini sesuai dengan teori manajemen yaitu proses yang dilakukan untuk memastikan seluruh rangkaian kegiatan yang telah direncanakan, diorganisasikan, diimplementasikan, dan dilakukan pengawasan bisa berjalan sesuai dengan target yang diharapkan. Sebagai mana yang dilakukan kepala sekolah dalam hal memanajemen menang harus sesuai dengan proses manajemen secara umum mengikuti langkah langkah merencanakan, mengorganisasikan, mengimplementasikan dan mengendalikan atau mengontrol.

\section{Faktor Pendukung dan Penghambat Pendidikan Inklusi di SMAN 1 Padangan Bojonegoro}

Setiap institusi atau lembaga pasti mempunyai faktor pendukung dan penghambat dalam pelaksanaan program kegiatan. Adapun faktor pendukung dan penghambat manajemen pendidikan inklusi di SMAN 1 Padangan sebagai berikut:

a. Faktor pendukung

Program pendidikan inklusi ini mendapat dukungan penuh dari pihak pemangku kebijakan kabupaten Bojonegoro. Karena memang di Bojonegoro sendiri menerapkan program ramah inklusi untuk setiap lembaga sekolah. Untuk menunjang keberjalanan program pendidikan inklusi guru atau tenaga pendidik sudah di bekali wawasan terkait pendidikan inklusi dan juga fasilitas untuk program inklusi. Selain itu aspek Solidaritas dari seluruh elemen tenaga pendidik dan kependidikan menjadi salah satu faktor pendukung dalam keberjalanan program pendidikan inklusi.

b. Faktor penghambat

Tidak adaan peserta didik di setiap tahun ajaran baru dan juga kurangnya konsistensi kesabaran dari tenaga pendidik dalam mendampingi peserta didik berkebutuhan khusus, tolak ukur keberhasilan metode dan problem-problem program tindak mampu terevaluasi dengan baik Hal tersebut yang menjadi faktor penghambat keberjalanan program manajemen pendidikan inklusi di SMAN 1 Padangan ini. 


\section{Kesimpulan}

Berdasarkan hasil penelitian ini, ada dua hal sesuai rumusan masalah penelitian yang bisa disimpulkan sebagai berikut:

1. Manajemen Pendidikan Inklusi di SMAN 1 Padangan Bojonegoro

a. Perencanaan (Planning)

Menetapkan tujuan, menyusun struktur, merumuskan keadaan, mengelola SDM, dan pengembangan metode pembelajaran.

b. Pengorganisasian (Organizing)

Sekelompok orang yang mau bekerja sama, ada tujuan yang hendak di capai, ada pekerjaan yang di kerjakan, ada pembagian tugas yang jelas, pengelompokkan kegiatan, menyediakan alat-alat yang di butuhkan untuk aktivitas organisasi, ada pendelegasian wewenang antara atasan dan bawahan dan pembuatan struktur organisasi yang efektif dan efisien.

c. Pelaksanaan (Actuanting)

Mencukupi berbagai sarana penunjang yang sangat di perlukan oleh bapak ibu guru dalam hal pengajaran khususnya juga dalam hal pengembangan program pendidikan inklusi. Dan selalu memberikan dorongan motivasi terhadap semua warga sekolah terutama peserta didik.

d. Pengawasan ( controlling)

Kerjasama yang kuat dengan berbagai pihak khususnya waka kesiswaan dan kurukulum. Dengan di bantu waka kurikulum dan kesiswaan maka informasi dapat segera tersampaikan.

2. Faktor pendukung dan penghambat manajemen pendidikan inklusi di SMAN1 Padangan

Program pendidikan inklusi di SMAN 1 Padangan, terdapat berbagai faktor pendukung dan penghabat dalam program manajemen pendidikan inklusi yaitu program pendidikan inklusi ini mendapat dukungan penuh dari pihak pemangku kebijakan kabupaten Bojonegoro, yang kedua yaitu keberjalanan program pendidikan inklusi guru atau tenaga pendidik sudah di bekali wawasan terkait pendidikan inklusi dan juga fasilitas untuk program inklusi berbentuk sosialisasi dan pelatihan, dan yang terakhir adalah aspek Solidaritas dari seluruh elemen tenaga pendidik dan kependidikan menjadi salah satu faktor pendukung dalam keberjalanan program pendidikan inklusi.

Selain itu faktor penghabat program manajemen pendidikan inklusi di SMAN1 Padangan juga menjadi salah satu fokus utama dalam pengembangan program manajemen pendidikan inklusi, faktor penghambat program manajemen pendidikan inklusi yaitu sulitnya mendapatkan peserta didik yang tergolong membutuhkan pendidikan inklusi di setiap tahun ajaran baru yang kedua kurangnya konsistensi kesabaran dari tenaga pendidik dalam mendampingi peserta didik berkebutuhan khusus, tolak ukur keberhasilan metode dan problem-problem program tidak mampu terevaluasi dengan baik. Hal tersebut yang menjadi faktor penghambat keberjalanan program manajemen pendidikan inklusi di SMAN 1 Padangan ini

\section{Daftar Kepustakaan}

Ro'fah dan Andayani, Inklusi Pada Pendidikan Tinggi: Best Practices Pembelajaran dan Pelayanan Adaptif Bagi Mahasiswa Difable Netra, Yogyakarta: PSLD UIN SuKa, 2010.

UU RI No. 20 tahun 2003. Tentang Sistem Pendidikan Nasional, Jakarta: Cemerlang, 2003.

Malik Fajar, Holistika Pemikiran Pendidikan. Jakarta: Raja Grafindo Persada, 2005.

Abdul Latif, Pendidikan Berbasis Nilai Kemasyarakatan, Bandung: Refika Aditama, 2007.

Lexy J.Moleong, Metodologi PenelitianKualitatf, Bandung: PT Remaja Rosdakarya,2014 
Nanda Rizki Wiliyanto

Eko Sugiarto, Menyusun Proposal Penelitian Kualitatif: Skripsi dan Tesis: Suaka Media, Yogyakarta : Diandra Kreatif, 2017.

Lexy, J. Moleong, Metodologi Penelitian Kualitatif Edisi Revisi, Bandung : PT Remaja Rosdakarya offset, cet.33, 2014.

Saifudin Azwar, Metode Penelitian, Yogyakarta: PT Pusaka Pelajar,2005.

Nana Syaodah Sukamdinata, Metode Penelitian Pendidikan, Bandung: PT Remaja Rosdakarya, 2008

Sugiyono, Metode Penelitian, Bandung: Penerbit Alfa Beta, 2015

Suharsimi Arikunto, Prosedur Penelitian: Suatu Pendekatan Praktek, Jakarta: PT Rineka Cipta, 2002.

Sugiyono, Metode Penelitian Pendidikan, : Pendekatan Kuantitatif, Kualitatif, dan R\&D, Bandung: Alfabeta, 2016. 